\title{
Improving the Ability to Know the Concept of Numbers Through the Game of Fishing Numbers in Integrated Islamic Kindergarten Adzkia III Padang
}

\author{
Iswi Apsari ${ }^{1}$ and Dadan Suryana ${ }^{2}$ \\ ${ }^{1}$ Early Childhood Education Department, Padang State University, Padang, Indonesia, iswi_sastro@yahoo.co.id \\ ${ }^{2}$ Early Childhood Education Department, Padang State University, Padang, Indonesia, dadan.suryana@yahoo.com
}

\begin{abstract}
Early childhood is an individual who is undergoing a process of rapid growth and development even said to be a developmental leap because that early age is said to be a golden age (golden age). This study aims to improve the ability to recognize the concept of numbers of children through the game of fishing numbers in the Integrated Islamic Kindergarten Adzkia III Padang. This research is a Class Action Research (CAR) conducted in the form of cycles, where each cycle is held 3 times. In each cycle carried out through 4 stages, namely planning, implementation, observation and reflection. The data collection tool used was observation. The subjects of this study were class B 4 children, amounting to 22 children consisting of 12 boys and 10 girls. The instrument in this study used observation sheets. The results of this study are through the fishing game numbers can improve the ability to recognize the concept of children's numbers. In the first cycle data obtained the success rate of children with an average percentage of very good $35 \%$ and in the second cycle the success rate of children increased to $88 \%$. It can be concluded that the research has been successful because it has reached very well developed criteria.
\end{abstract}

Keywords: Concept of Numbers, Games, Fishing Numbers, PTK

\section{INTRODUCTION}

Early childhood is a very important period for the subsequent development of life because at an early age is a sensitive period or a golden age period as for opinions (Hurlock, 1980) childhood determines adulthood, as the morning predicts a new day the first years are a critical time for early childhood development. Early childhood education is one form of application of education that emphasizes the basic foundation towards growth, development of physical coordination of soft and hard motor, and intelligence (mind, creativity, emotional intelligence, and spiritual intelligence (Rakimahwati, 2014). While development at an early age covers physical and motor development, cognitive, social emotional and language according to Ebbeck (Suryana, 2018) is the most intense growth period and as well as the busiest, as for aspects of development that exist in children include: cognitive, physical motor, and (social emotional) aspects (Yaswinda, Yulsyofrien, 2018). Every aspect must be well developed and in accordance with the stages of development, aspects of development and abilities of early childhood consists of the development of physical abilities, cognitive, language, social, religious and moral as well as arts. At this time the process of growth and development in various aspects is experiencing a rapid period in the span of development of human life. One aspect that needs to be stimulated in kindergarten is the cognitive aspect

Cognitive development is one aspect of development that is important for developing children's thinking abilities. The cognitive development of children in recognizing numbers is very important to be mastered by children, because it will be the basis for the mastery of further mathematical concepts at the next level of education. Ideally the ability of mathematical logic in kindergarten on the ability to count in the beginning, namely, numerating or mentioning numbers 1-10, recognizing the concept of symbols numbers 1-10, connecting the concepts of numbers and symbols of numbers, and recognize the concepts of the same and not the same. In the beginning, children will learn the names of numbers but have not been able to judge the symbols, for example they can say, one, two, three, but are unable to understand their meaning. Often numbers are referred to as a series of words without meaning related to that number. In line with the growth and experience gained, the child will be able to understand the meaning of a number. To grow and develop skills to recognize the concept of numbers, it can be done through play activities. In addition to producing optimal learning, teachers are also required to be creative in making interesting play tools for children. 
Cognitive ability is one of the areas of development in kindergarten. This ability development is directed so that children are able to solve simple problems in their daily lives, develop cognitive abilities and recognize conditions that occur in the surrounding environment. According to (Sujiono, Yuliani \& Sujiono, 2010) said cognitive is a process of thinking that is the ability of individuals to connect, assess and consider an event or event.

Meanwhile, according to (Susanto, 2011) argues, cognitive is "a process of thinking, namely the ability of individuals to connect, assess, and consider an event or event". Through cognitive development, children are expected to understand situations that occur in their environment, such as the causes of floods, toothaches, and so on.

From the above opinion it can be concluded that cognitive ability is the ability possessed by someone in solving a problem through the process of thinking, connecting, assessing, and considering adjusting to achieve goals. Cognitive abilities are directed so that children are able to develop their perceptions based on what they see, hear and feel, so that children will have a complete and comprehensive understanding. In addition, children are also directed to be able to understand the concept of numbers.

Numbers are part of the concept of numbers because numbers are symbols or names of the concept of numbers as Wahyudi, et al (Wahyudi, 2005) think that numbers are the understanding that one is one, two is two, and so on. The introduction of the concept of numbers in children can be started through work and play experiences. According to Alexander in (Siswanto., 2008) the concept of numbers is a way of recognizing the concrete and fun for children, through everything that is in the child's environment and utilizing and counting the number of toys that children really like. And in the opinion (Jordan, N. C., Kaplan, D., Locuniak, M. N., \& Ramineni, 2007) Even at the beginning of kindergarten, the senses of number are highly correlated with the end of mathematical achievement

Unlimited opportunities provided by the teacher to stimulate children's understanding of numbers through daily routines. Children will begin to develop when the child is playing, because introducing the concept of numbers have been scattered around the child such as: size, age, slices of cake, and the number of fruits and those closest to him like himself like his limbs like toes and the number of limbs .

Children's interest in numbers will grow very naturally naturally if they are introduced concretely and clarify and arrange the concepts of numbers are the basis of the early mathematics learning process that is to be built from an early age. Understanding the concept of numbers develops over time and the opportunity to repeat work with a group of objects and compare the amount. Counting is a way of learning about the name of a number, then using the name of the number to identify the number of objects. Understanding the concept of numbers involves thinking about how much or how many including counting, adding up the most important thing is to understand the concept of numbers.

Explanation from the experts above can be concluded that the understanding of the concept of numbers is a collection of objects or numbers that can provide an understanding. The purpose of introducing the concept of numbers above is to develop skills to recognize the concept of numbers and symbols of numbers needed in everyday life and also the basis for developing children's mathematical abilities. In (Sujiono, Yuliani \& Sujiono, 2010) there are several benefits of introducing the concept of numbers to children, namely: 1) Practicing the sensitivity of children's thinking, 2) Developing imagination, 3) Stimulating children's activities, 4) Facilitating understanding of children will recognize the concept of numbers, 5) Helping facilitate to remember the number of objects. The benefit of introducing the concept of numbers according to Piget and Lorton in (Aqib Zainal, 2009) is that children can understand the concept through the experience of working and playing with concrete objects, with symbols. From the explanation, the benefit of introducing the concept of numbers is to help children understand mathematical concepts, for example, children recognize the number of objects and develop children's cognitive.

Play is an activity that can cause pleasure in children, because in playing children are free to do activities that they like. Through play activities children learn to recognize their environment and learn to interact with their environment. (Mutiah, 2012) states playing is a very important activity for children's growth and development. Play must be based on child initiative and the child's own decision. Playing should be done with pleasure, so that all fun play activities will result in a learning process for children. Meanwhile according to (Hurlock, 1980) play is an activity carried out on the basis of a pleasure and without considering the final results, the activity is carried out voluntarily without coercion or pressure from outside parties.

Based on the above opinion it can be concluded that from some of these opinions playing is playing is an activity that is loved by young children without thinking about the results and goals, only to achieve satisfaction in the child. According to (Jordan, N. C., Kaplan, D., Locuniak, M. N., \& Ramineni, 2007) say the characteristics of playing in kindergarten as follows: 1) Play is relatively free from the rules, 2) Play drama, 3) Play is more focused on activities than the final result, 4) Play requires interaction in children's involvement. According to Hariwijaya (2009: 104) the characteristics of play in children are: 1) Play is carried out voluntarily not coercion, 2) Play is a fun activity so that it can be enjoyed by children, 3) Without coercion the play activity itself is fun, 4 ) The purpose of play is the play activity itself, 5) Demanding active participation in play activities, 6) Children can freely express their expressions by playing.

Play has an important role for the cognitive and social development of children, the function of play can also affect language development, discipline, moral development, creativity and physical development of 
motor children. Hetherington \& Parke in (Whidiawati, 2011) suggested the function of play and interaction in games has an important role for children's cognitive and social development.

The game tool is a learning resource used by children to fulfill their instincts of play, there are those that are pairs of pairs, classifying, combining, looking for their equivalents, arranging, shaping, knocking, perfecting a design and composing according to their complete shape (Endro Joko Wibowo, 2013). The optimal game tool is a game tool that is capable of stimulating and attracting children's interests while at the same time able to develop various types of children's abilities and does not limit only one specific activity. "Openeded Plaything" . Game tools are material for children to develop themselves that involve all aspects of development, with children's play tools will get input for their knowledge to remember. Meanwhile, in the opinion (Ramani, G. B., \& Siegler, 2008) the experience of playing board games is positively correlated with numerical knowledge. Thus, playing number board games with children from low income backgrounds can increase their numerical knowledge at the beginning of school.

Play as a form of learning activities in kindergarten must play creative and fun for children. For this reason, teachers are required to always provide facilities in the form of play equipment that suits the needs and interests of children. According to (Aqib Zainal, 2009) educational games are playful and creative tools. Ismail (Ismail, 2006) also explains that the educational game is a very fun activity and is an educational method or tool that is educational.

Furthermore Eliyawati (Mutiah, 2012) argues that educational game tools are game tools specifically designed for the benefit of educational tools that have the characteristics of: a) Can be used in various ways meaning can be played with various benefits, and various forms, b ) Aimed primarily at preschoolers and functioning to develop various aspects of children's intelligence and motor development, c) Safe for children, d) Designed to encourage children's activities and creativity.

Educational games are tools that are used to play by children who are fun that can trigger creativity and fulfill all aspects of child development. While the number fishing game in the opinion of (Sujiono, 2007) the number fishing game is a game that aims to pair the number with the symbol number. (Endro Joko Wibowo, 2013) argues that the number fishing game is a game that connects between children and numbers in everyday life. Meanwhile, in the opinion (Watanabe, 2001) the cards with which fishing games are complicated and interesting can be enjoyed. The card set for the game consists of a point card and a player card.

Through numbers fishing games, children can get to know the concept of numbers, that is, children are able to pair numbers according to the number of objects, and recognize the shapes of numbers. This number game fishing tool is one of the educational games, wherein the tool and the material uses a used box that will be formed into the form of number cards, and pictures of objects according to the theme while the fishing rod uses a small bamboo on the ends tied with yarn and the ends of the yarn tied to a magnet. The making of a game for fishing for numbers is based on basic learning competencies that aim to make children able to understand simple mathematical concepts, namely, the concept of numbers. While learning outcomes are children can understand the concept of numbers. And the indicator is to spell out (recognize) the concept of numbers with objects up to 20 , make a sequence of numbers 1-20 with objects, and connect / pair symbols of numbers with objects up to 10 . This game of fishing for numbers to develop aspects of basic abilities child from its cognitive aspects. In the fishing game for numbers, children will be given the opportunity to lure out the numbers provided by the teacher, then the child mentions the numbers that he fished. Then the child takes the picture that has been provided as many numbers as he has lured. Thus through the fishing game this number can improve the ability of children to recognize the concept of numbers.

\section{RESEARCH METHODS}

This type of research is Classroom Action Research (CAR), which is an activity carried out in the classroom. (Arikunto, 2006) states that classroom action research is an examination of learning activities in the form of an action, which is deliberately raised and occurs in a class simultaneously. The action is given by the teacher or by the teacher's direction done by the student. (Arikunto, 2006) revealed that in class action research there are four stages that are commonly passed, namely (1) planning, (2) implementation, (3) observation, and (4) reflection. By conducting classroom action research, teachers can continuously improve their performance and find solutions to problems that arise in their own classrooms, by applying various relevant theories and learning techniques effectively.

\section{RESEARCH RESULT Description of Cycle I}

Cycle I conducted 3 meetings. The first meeting was held on Monday 16 September 2019, the second meeting was on Monday 23 September 2019, the third meeting was on Monday 30 September 2019. Overall the Cycle I actions could be carried out according to the plan that had been made previously. The first meeting was held on Monday 16 September 2019.

\section{a) First Cycle I Meeting}

Based on table 1 the results of observations of the ability to recognize the concept of numbers of children in the learning process in fishing activities to the number one meeting in the first cycle (after the action) that is in the first aspect of development, namely children are able to mention numbers that are in the very high category totaling 3 people with a percentage of $14 \%$, high children are 8 people with a percentage of $36 \%$ and low children are 11 people with a percentage of $50 \%$. The second aspect of development, children can rank numbers correctly that 
are in the very high category 3 people with a percentage of $14 \%$, a high number of 5 people with a percentage of $23 \%$, children who are in the low category are 14 people with a percentage of $64 \%$.

Table 1. Observation Results on Improvement of Women Recognizing the Concept of Numbers Through Game of Fishing Numbers at TKIT Adzkia III Padang at the 1st Cycle I Meeting (After Action

\begin{tabular}{|c|c|c|c|c|c|c|c|}
\hline \multirow{3}{*}{ NO } & \multirow{3}{*}{ Aspek } & \multicolumn{6}{|c|}{ Score } \\
\hline & & \multicolumn{2}{|c|}{ ST } & \multicolumn{2}{|c|}{$\mathbf{T}$} & \multicolumn{2}{|c|}{$\mathbf{R}$} \\
\hline & & $\mathbf{F}$ & $\%$ & $\mathbf{F}$ & $\%$ & $\mathbf{F}$ & $\%$ \\
\hline 1. & $\begin{array}{l}\text { The child is } \\
\text { able to say the } \\
\text { number }\end{array}$ & 3 & 14 & 8 & 36 & 11 & 50 \\
\hline 2. & $\begin{array}{l}\text { Children can } \\
\text { sort numbers } \\
\text { correctly }\end{array}$ & 3 & 14 & 5 & 23 & 14 & 64 \\
\hline 3. & Average Value & 2 & 9 & 5 & 23 & 15 & 68 \\
\hline & Average value & 3 & 12 & 6 & 27 & 13 & 61 \\
\hline
\end{tabular}

The third aspect of development, children are able to pair numbers with objects that are in the very high category amounted to 2 people with a percentage of $9 \%$, a high number of 5 people with a percentage of $23 \%$, and children who are in the low category numbered 15 people with a percentage of $68 \%$.

b) Second Meeting in Cycle I

The second meeting was held on Monday September 23 2019

Table 2. Observation Results of Increased Ability to Recognize the Concept of Numbers through Game of Numbers Fishing at TKIT Adzkia III at the 2nd Cycle I Meeting (After Action)

\begin{tabular}{|c|c|c|c|c|c|c|c|}
\hline \multirow{2}{*}{ No } & \multirow{2}{*}{ Aspect } & \multicolumn{6}{|c|}{ Score } \\
\cline { 3 - 8 } & & \multicolumn{2}{|c|}{ ST } & \multicolumn{2}{|c|}{ T } & \multicolumn{2}{|c|}{ R } \\
\cline { 3 - 8 } f. & $\begin{array}{c}\text { The child is able } \\
\text { to say the } \\
\text { number }\end{array}$ & 6 & 27 & 10 & 45 & 6 & 27 \\
\hline 2. & $\begin{array}{c}\text { Children can sort } \\
\text { numbers } \\
\text { correctly }\end{array}$ & 7 & 32 & 8 & 36 & 7 & 32 \\
\hline 3. & Average Value & 4 & 18 & 7 & 32 & 11 & 50 \\
\hline \multicolumn{2}{|c|}{ Average value } & 6 & 26 & 8 & 38 & 8 & 36 \\
\hline
\end{tabular}

Get to know the concept of the number of children in the learning process in fishing activities to the second meeting number in the first cycle (after the action), namely in the first aspect of development, namely children are able to mention numbers that are in the very high category amounted to 6 people with a percentage of $27 \%$, high numbered children 10 people with a percentage of $45 \%$ and low children amounting to 6 people with a percentage of $27 \%$ The second aspect of development, children can rank numbers correctly that are in the very high category 7 people with a percentage of $32 \%$, a high number of 8 people with a percentage of $36 \%$, children in the low category are 7 people with a percentage of $32 \%$. The third aspect of development, children can rank numbers correctly that are in the very high category 4 people with a percentage of $18 \%$, a high number of 7 people with a percentage of $32 \%$, and children who are in the low category amounted to 11 people with a percentage of $50 \%$.

\section{c) Third Meeting} 2019.

The third meeting was held on Friday 30 September

Table 3. Observation Results of Increased Ability to Recognize the Concept of Numbers through Numbers Fishing Game at TK Adzkia III Padang at the 3rd Cycle I Meeting (After Action)

\begin{tabular}{|l|l|l|l|l|l|l|l|}
\hline \multirow{2}{*}{ No } & \multirow{2}{*}{ Aspect } & \multicolumn{6}{|c|}{ Score } \\
\cline { 3 - 8 } & & \multicolumn{2}{|c|}{ ST } & \multicolumn{2}{|c|}{ T } & \multicolumn{2}{c|}{ R } \\
\cline { 3 - 8 } 1. & $\begin{array}{l}\text { The child is able } \\
\text { to say the } \\
\text { number }\end{array}$ & 8 & 36 & 10 & 45 & 4 & 18 \\
\hline 2. & $\begin{array}{l}\text { Children can sort } \\
\text { numbers } \\
\text { correctly }\end{array}$ & 9 & 41 & 9 & 41 & 4 & 18 \\
\hline 3. & Average Value & 6 & 27 & 7 & 32 & 9 & 41 \\
\hline & Average value & 8 & 35 & 8 & 39 & 6 & 26 \\
\hline
\end{tabular}

Based on table 1.3 the results of observations of the ability to recognize the concept of numbers of children in the learning process in fishing activities to the third meeting number in the first cycle (after action), namely the first development aspect, which is able to mention numbers that are in the very high category amounted to 8 people with a percentage of $36 \%$, high children numbered 10 people with a percentage of $45 \%$ and low children numbered 4 people with a percentage of $18 \%$. The second aspect of development, children can rank numbers correctly that are in the very high category 9 people with a percentage of $41 \%$, a high number of 9 people with a percentage of $41 \%$, children who are in the low category are 4 people with a percentage of $18 \%$. The third aspect of development, children are able to pair the numbers with images that are in the very high category 6 people with a percentage of $27 \%$, a high number of 7 people with a percentage of $32 \%$, and children who are in the low category amounting to 9 people with a percentage of $41 \%$

\section{d) Reflection on Cycle I}

The implementation of learning in the first cycle was in accordance with the plan, based on observations the impact of learning had increased, this was seen from:

1) Increased Ability to Recognize the Concept of Numbers Through Fishing Games Numbers have increased, namely: 
(a) The child is able to mention a number with a very high value from the value of $14 \%$ at meeting 1 , to $27 \%$ at meeting 2 and increased to $36 \%$ at meeting 3 .

(b) Children can rank the number of hearing correctly with a very high value from the value of $14 \%$ at meeting 1 , to $32 \%$ at meeting 2 and increase to $41 \%$ at meeting 3

(c) The child is able to pair the numbers correctly with a very high value of $9 \%$ at meeting 1 , to $18 \%$ at meeting 2 and to increase to $27 \%$ at meeting 3

\section{Description of Cycle II}

Cycle II held 3 meetings. The first meeting was held on Monday 16 November 2015, the second meeting was on Thursday 19 November 2015. Overall the Cycle II actions could be carried out in accordance with the plans that had been made previously.

\section{a) First Cycle II Meeting}

The first meeting was held on Monday 16 November 2015.

Table 4. Observation Results of Increased Ability to Recognize the Concept of Numbers through Game of Numbers Fishing in TKIT Adzkia III Padang at 1st Cycle II Meeting (After Action)

\begin{tabular}{|l|l|l|l|l|l|l|l|}
\hline \multirow{2}{*}{ No } & \multirow{2}{*}{ Aspect } & \multicolumn{6}{|c|}{ Score } \\
\cline { 3 - 9 } & \multicolumn{2}{|c|}{ ST } & \multicolumn{2}{|c|}{ T } & \multicolumn{2}{c|}{ R } \\
\cline { 3 - 8 } 1. & $\begin{array}{l}\text { The child is able } \\
\text { to say the } \\
\text { number }\end{array}$ & 12 & 55 & 8 & 36 & 2 & 9 \\
\hline 2. & $\begin{array}{l}\text { Children can sort } \\
\text { numbers } \\
\text { correctly }\end{array}$ & 11 & 50 & 7 & 32 & 4 & 18 \\
\hline 3. & Average Value & 10 & 45 & 8 & 36 & 4 & 18 \\
\hline \multicolumn{1}{|c|}{ Average value } & 8 & 11 & 50 & 8 & 35 & 3 \\
\hline
\end{tabular}

Getting to know the concept of the number of children in the learning process in fishing activities to the number one meeting in the second cycle (after the action) that is in the first aspect of development, that is the child is able to mention the numbers that are in the very high category amounted to 12 people with a percentage of 55\%, high numbered children 8 people with a percentage of $36 \%$ and low children numbered 2 people with a percentage of $9 \%$. The second aspect of development, children can rank numbers correctly that are in the very high category 11 people with a percentage of $50 \%$, a high number of 7 people with a percentage of $32 \%$, children who are in the low category are 4 people with a percentage of $18 \%$. The third aspect of development, children are able to pair numbers with objects that are in the very high category totaling 10 people with a percentage of $45 \%$, a high number of 8 people with a percentage of $36 \%$, and children who are in the low category totaling 4 people with a percentage of $18 \%$.

\section{b) Second Meeting in Cycle II}

The second meeting was held on Thursday 9 November 2015

Table 5. Observation Results of Increased Ability to Recognize the Concept of Numbers through Game of Numbers Fishing in TKIT Adzkia III Padang at 2nd Cycle II Meeting (After Action)

\begin{tabular}{|l|l|l|l|l|l|l|l|}
\hline \multirow{2}{*}{ No } & \multirow{2}{*}{ Aspect } & \multicolumn{6}{|c|}{ Score } \\
\cline { 3 - 8 } & & \multicolumn{2}{|c|}{ ST } & \multicolumn{2}{|c|}{ T } & \multicolumn{3}{|c|}{ R } \\
\cline { 3 - 8 } 1. & $\begin{array}{l}\text { The child is } \\
\text { able to say } \\
\text { the number }\end{array}$ & 20 & 91 & 2 & 9 & 0 & 0 \\
\hline 2. & $\begin{array}{l}\text { Children can } \\
\text { sort numbers } \\
\text { correctly }\end{array}$ & 19 & 86 & 1 & 5 & 1 & 5 \\
\hline 3. & $\begin{array}{l}\text { Average } \\
\text { Value }\end{array}$ & 19 & 86 & 2 & 9 & 1 & 5 \\
\hline
\end{tabular}

Based on table 2.2 the results of observations of development know the concept of the number of children in the process of learning to provoke the second meeting number in the second cycle (after the action), namely in the first aspect of development, namely children are able to mention numbers that are in the very high category totaling 20 people with a percentage of $91 \%$, children in the high category are 2 people with a percentage of $9 \%$. and children in the low category are 0 . The second development aspect, children can sort numbers correctly in the very high category 19 people with a percentage of $86 \%$, children in the category high number of people with a percentage of $5 \%$, children who are in the low category amounted to 1 person with a percentage of $5 \%$. The third aspect of development, children are able to pair numbers with objects that are in the very high category 19 people with a percentage of $86 \%$, in the high category there are 2 people with a percentage of $9 \%$, and children who are in the low category are 1 person with a percentage of $5 \%$.

\section{d) Cycle Reflection II}

The implementation of learning activities in the second cycle is in accordance with the plan, based on observations, it can be seen from the results of the fishing game that numbers are increasing, this can be seen from:

(1) The ability of children to mention very high numbers from $55 \%$ increased to $91 \%$

(2) The child's ability to rank numbers correctly is very high from $50 \%$ to $86 \%$

(3) The ability of children to pair numbers with objects is very high from $45 \%$ to an increase of $86 \%$

\section{CONCLUSION}

Several conclusions can be made as follows:

1. Through the activity of mentioning numbers can increase the ability to recognize the concept of child numbers, this can be seen by an increase in the 
percentage of the initial condition of $9 \%$, the first cycle of children which is very high category amounted to $36 \%$ and increased in cycle II to $91 \%$.

2. Through sorting activities can increase the ability to recognize the concept of child numbers, it is seen an increase in the percentage of the initial condition of $5 \%$, the first cycle of children which is very high category amounted to $42 \%$ and increased in cycle II to $86 \%$.

3. Through the activity of pairing numbers with objects can improve the ability to recognize the concept of child numbers, this is seen by an increase in the percentage of the initial condition of $5 \%$, the first cycle of the very high category of children is $27 \%$ and increased in cycle II to $86 \%$.

4. Through the game of fishing numbers can improve the ability to recognize the concept of numbers B4 TKIT Adzkia III Padang children.

\section{REFERENCES}

[1] Aqib Zainal. (2009). Belajar dan Pembelajaran di Taman Kanak-Kanak. Bandung: Yarama widya.

[2] Arikunto, S. (2006). Prosedur Penelitian: Suatu Pendekatan Praktek. Jakarta: Rineka Cipta.

[3] Endro Joko Wibowo. (2013). Media Pembelajaran Interaktif Matematika Untuk Siswa Sekolah Dasar Kelas IV. UNSA.

[4] Hurlock, B. E. (1980). Psikologi Perkembangan suatu Pendekatan Sepanjang Rentang Kehidupan (Jilid I). Jakarta: Erlangga.

[5] Ismail, A. (2006). Education Games. Yogyakarta: Pilar Media.

[6] Jordan, N. C., Kaplan, D., Locuniak, M. N., \& Ramineni, C. (2007). Predicting First-Grade Math Achievement from Developmental Number Sense Trajectories, 22. https://doi.org/22(1),36-46

[7] Mutiah, D. (2012). Psikologi Bermain Anak Usia Dini (2nd ed.). Jakarta: Kencana Prenada Media Group.

[8] Rakimahwati. (2014). Indonesian Journal of Early Childhood Character Development through Dance Learning in an Early Childhood Setting, 3(2), 102 107. https://doi.org/10.15294/ijeces.v3i2.9490

[9] Ramani, G. B., \& Siegler, R. S. (2008). Promoting Broad and Stable Improvements in Low-Income Children's Numerical Knowledge Through Playing Number Board Games, 2. https://doi.org/375.394
[10] Siswanto. (2008). Mendidik Anak Dengan Permainan Kreatif. Yogyakarta: Anggota IKAPI.

[11] Sujiono, Yuliani \& Sujiono, B. (2010). Bermain Kreatif Berbasis Kecerdasan jamak. Jakarta: Indeks.

[12] Sujiono, B. (2007). Metode Pengembangan Fisik (Edisi Revisi). Jakarta: Universitas Terbuka.

[13] Suryana, D. (2018). Pendidikan Anak Usia Dini Stimulasi dan Aspek Perkembangan Anak (Pertama). Jakarta: Prenadamedia Group.

[14] Susanto, A. (2011). Perkembangan Anak Usia Dini. Jakarta: Kencana Prenada Media Group.

[15] Wahyudi, dkk. (2005). Program Pendidikan Anak Usia Dini Di Pra Sekolah Islam. Jakarta: Gramedia.

[16] Watanabe, S. (2001). No Title Set of cards used for playing a card game simulating fishing. https://doi.org/6,332,615

[17] Whidiawati, N. (2011). Pengaruh Pembelajaran Gerak dan Lagu Dalam Meningkatkan Kecerdasan Musikal Dan Kecerdasan Kinestetik Anak Usia Dini, (2), 220-228.

[18] Yaswinda, Yulsyofrien, F. M. (2018). Pengembangan Bahasa Pembelajaran Sains Berbasis Multisensori Ekologi Bagi Guru Paud Kecamatan Tilatang Kamang Kabupaten Agam, 2. 